\title{
Protein Profile of the Acquired Enamel Pellicle after Rinsing with Whole Milk, Fat-Free Milk, and Water: An in vivo Study
}

\author{
Luiza P.S. Cassiano $^{a}$ Talita M.S. Ventura ${ }^{a}$ Cintia M.S. Silva ${ }^{a}$ Aline L. Leite $^{a}$

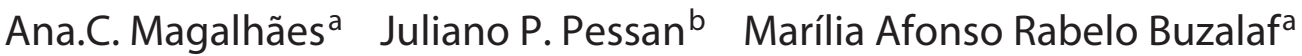 \\ ${ }^{a}$ Department of Biological Sciences, Bauru School of Dentistry, University of São Paulo, Bauru, and \\ ${ }^{\mathrm{b}}$ Araçatuba Dental School, Universidade Estadual Paulista (UNESP), Araçatuba, Brazil
}

\section{Keywords}

Acquired pellicle · Caries · Enamel · Erosion · Milk ·

Proteomics

\begin{abstract}
This study detected changes in the protein profile of the acquired enamel pellicle (AEP) formed in vivo after rinsing with whole milk, fat-free milk, or water. Nine subjects in good oral condition took part in the study. The acquired pellicle was formed in the morning, for $120 \mathrm{~min}$, after prophylaxis with pumice. Following this, the volunteers rinsed with $10 \mathrm{~mL}$ of whole milk, fat-free milk, or deionized water for $30 \mathrm{~s}$, following a blinded crossover protocol. After $60 \mathrm{~min}$, the pellicle was collected with filter paper soaked in 3\% citric acid and processed for analysis by liquid chromatography-electrospray ionization tandem mass spectrometry. The obtained tandem mass spectrometry spectra were searched against a human protein database (Swiss-Prot). The proteomic data related to protein quantification were analysed using the PLGS software. A total of 260 proteins were successfully identified in the AEP samples collected from all groups. Forty-nine were common to all 3 groups, while 72, 62, and 49 were specific to the groups rinsing with whole milk, fat-free milk, and water, respectively. Some were typical compo-
\end{abstract}

\section{KARGER}

(c) 2018 S. Karger AG, Basel

E-Mail karger@karger.com

www.karger.com/cre nents of the AEP, such as cystatin-B, cystatin-SN, isoforms of a-amylase, IgA and IgG, lysozyme C, protein S100 A78, histatin-1, proline-rich protein 27 , statherin, and lactotransferrin. Other proteins are not commonly described as part of the AEP but could act in defence of the organism against pathogens. Distinct proteomic profiles were found in the AEP after rinsing with whole or fat-free milk, which could have an impact on bacterial adhesion and tooth dissolution. The use of fat-free milk could favourably modulate the adhesion of bacteria to the AEP as well as biofilm formation when compared with whole milk.

(c) 2018 S. Karger AG, Basel

The acquired enamel pellicle (AEP) is a thin acellular film formed on the tooth's surface by selective adsorption of proteins. These adsorbed proteins originate mainly from the salivary glands, but also from microorganisms, the oral mucosa, and the gingival crevicular fluid [Siqueira et al., 2012]. Typical proteins already identified in the AEP include IgA, acidic proline-rich protein (PRP), cystatin, mucin, lactoferrin, amylase, and lysozyme [Lendenmann et al., 2000]. The AEP acts as a semipermeable barrier, participates in bacterial adhesion, and controls the dynamic mineral dissolution and precipitation processes 
[Hannig et al., 2004; Hara et al., 2006; Buzalaf et al., 2012; Vukosavljevic et al., 2014].

The colonization of bacteria begins through recognition of components from the AEP [Kolenbrander and London, 1993]. Streptococci and Actinomyces spp. are known to be early colonizers involved with the progression of dental plaque formation, and it is essential to determine if the type of microbiological succession will result in a healthy or an unhealthy plaque environment [ $\mathrm{Li}$ et al., 2004]. Some proteins described in the AEP can interact with bacteria, e.g., Streptococcus gordonii recognizes receptors from acidic PRP [Gibbons et al., 1991] and amylase [Scannapieco et al., 1989]; Actinomyces naeslundii binds to PRPs [Gibbons et al., 1988] and statherin [Scannapieco et al., 1989]; and Fusobacterium nucleatum binds to statherin [Scannapieco et al., 1989]. This clearly shows that the molecular composition and physicochemical properties of the pellicle determine the type of microbial colonization [Cheaib et al., 2015]. In this sense, it has been shown that dietary proteins such as casein influence the composition of the AEP, altering its physiological role, which could modify the ecological succession of the biofilm [Cheaib et al., 2015], which in turn might increase or decrease susceptibility to caries.

Bovine milk has important anticariogenic and cariostatic effects [Bowen et al., 1991; Warner et al., 2001]. These effects are attributed to the high buffer capacity, high concentrations of calcium and phosphate, and the presence of some proteins (such as $\alpha$ - and $\kappa$-casein), which reduce the adhesion of $S$. mutans and the activity of glucosyltransferase [Vacca-Smith and Bowen, 1998]. Also, the phosphopeptides released during casein proteolysis are likely to be involved in the prevention of enamel demineralization [Reynolds et al., 1999]. An in situ study observed the effect of $\kappa$-casein from bovine milk on the formation of the acquired pellicle at different times ( $30 \mathrm{~s}$, as well as 1, 5, 10, and $20 \mathrm{~min}$ ), showing that the film formed in the presence of milk compared to a control (water) exhibited a larger amount of proteins. In addition, some of these proteins had a different molecular weight when compared to the pellicle collected from the control group, having a different protein profile in the presence of bovine milk. The results in the presence of $\kappa$-casein also showed a different protein profile, but the amount of protein was constant all the time. These results indicate that the consumption of milk can alter the composition of the AEP [Vacca-Smith and Bowen, 2000].

Another possible mechanism of action of milk against tooth demineralization is the interaction between the lipids present in milk and the AEP [Vukosavljevic et al.,
2014], since lipids represent $25 \%$ of its dry weight [Slomiany et al., 1986]. Thus, it can be hypothesized that a lipid-enriched AEP would be more resistant in the event of exposure to acids, reducing the erosive wear [Kensche et al., 2013], as has been reported to occur for caries [Slomiany et al., 1986]. However, there is some controversy in the literature in this regard, since safflower oil has been shown to reduce the protective ability of the AEP against erosive demineralization in situ [Hannig et al., 2012]. It has also been shown that rinsing with whole milk before an erosive challenge significantly reduced erosive tooth loss, suggesting the formation of a protective layer on the tooth's surface [Magalhães et al., 2014]. It is possible that, in the clinical situation, exposure to whole milk could change the fat content and/or the protein profile of the AEP.

The present study took advantage of proteomic analysis to evaluate changes in the protein profile of the AEP formed after rinsing with whole milk compared with fatfree milk and deionized water. The null hypothesis tested was that rinsing with milk, regardless of its fat content, does not alter the protein composition of the AEP.

\section{Subjects and Methods}

Ethical Aspects and Subjects

Nine adult subjects took part in this study, which was approved by the Institutional Review Board of the Bauru School of Dentistry, University of São Paulo (CAAE 50695915.800005417). The sample size was based on studies recently conducted by our group, with a similar research protocol [Delecrode et al., 2015; Ventura et al., 2017]. Only volunteers who had good oral health (presenting full permanent dentition and no open cavities or deficient restorations), a stimulated salivary flow $>1 \mathrm{~mL} / \mathrm{min}$, an unstimulated salivary flow $>0.3 \mathrm{~mL} / \mathrm{min}$, a salivary $\mathrm{pH}>6$, and good systemic health and who were not using medicines that could alter the salivary composition or flow rate were eligible to participate. The subjects signed an informed consent document prior to the beginning of the study.

\section{In vivo Experiment}

During the in vivo experiment, the volunteers were instructed not to eat or drink any type of food. The experiment began in the morning to avoid circadian effects on the composition of the pellicle [Zimmerman et al., 2013]. The volunteers were submitted to dental prophylaxis, employing coarse pumice containing no additives, and the AEP was allowed to form for $2 \mathrm{~h}$. After that, the volunteers rinsed with $10 \mathrm{~mL}$ of whole milk, fat-free milk, or deionized water for $30 \mathrm{~s}$ [Vacca-Smith and Bowen, 2000], following a crossover protocol, being instructed to spit out the milk and not to rinse their mouth or eat or drink anything prior to AEP collection. After $1 \mathrm{~h}$, the AEP was collected from the labial surface of the teeth. The teeth from each quadrant were isolated with cotton rolls, washed with water, and dried by air. For the collection of AEP ma- 
terial, a $5 \times 10 \mathrm{~mm}$ electrode filter paper (Electrode Wick; Bio-Rad, Hercules, CA, USA) pre-soaked in 3\% citric acid was used [Siqueira et al., 2007]. The filter paper was rubbed (without pressure) on the labial surface of the teeth with the aid of tweezers. The filter paper was used to swipe the coronal two-thirds of the labial surfaces, spanning from the central incisor to the second molar. In each quadrant, a separate collection filter paper was used for AEP collection. A total of 4 collection strips from each participant were placed in a polypropylene microcentrifuge tube and kept frozen at $-80^{\circ} \mathrm{C}$ until used for proteomic analysis. This procedure was done in duplicate for each treatment to provide enough samples to be submitted to proteomic analysis.

\section{Proteomic Analysis}

Preparation of the AEP Samples

The microcentrifuge tubes containing the filter papers were removed from the $-80^{\circ} \mathrm{C}$ freezer. After defrosting, the papers were cut into small pieces with the aid of sterile scissors and tweezers. These small pieces from all volunteers were put together in a microcentrifuge tube, constituting a pool for each treatment (whole milk, fat-free milk, or water). The samples were pooled in order to obtain enough samples for analysis, as has been done in previous studies [Lee et al., 2013; Delecrode et al., 2015a; Ventura et al., 2017; de Souza-e-Silva et al., 2017].

Preparation of the AEP samples for proteomic analysis was done as previously reported [Ventura et al., 2017]. The papers were covered with a solution prepared with $6 \mathrm{M}$ urea and $2 \mathrm{M}$ thiourea in $50 \mathrm{~mm} \mathrm{AmBic} \mathrm{(ammonium} \mathrm{bicarbonate).} \mathrm{The} \mathrm{filter} \mathrm{papers} \mathrm{were}$ then centrifuged at $14,000 \mathrm{~g}$ for $10 \mathrm{~min}$ at $4^{\circ} \mathrm{C}$. The supernatant was separated from the precipitate and stored in another microcentrifuge tube. This procedure was conducted twice. Subsequently, the filter papers were transferred to plastic centrifuge tube filters (Corning Costar Spin-X; Sigma-Aldrich) and were centrifuged at $14,000 \mathrm{~g}$ for $10 \mathrm{~min}$ at $4^{\circ} \mathrm{C}$. The supernatant was collected and put together with the supernatants collected before. All the supernatants collected were transferred to a $15-\mathrm{mL}$ Falcon tube and $1.5 \times$ $\mathrm{V}$ of $50 \mathrm{~mm}$ AmBic was added (i.e., for $300 \mu \mathrm{L}$ of sample, $450 \mu \mathrm{L}$ of AmBic was added). The samples were then transferred to Falcon tubes containing a column for sample concentration (Amicon Ultra centrifugal filter units $10 \mathrm{kDa}$; Millipore), and centrifuged at $5,000 \mathrm{~g}$ at $25^{\circ} \mathrm{C}$ until the volume was reduced to $100-200 \mu \mathrm{L}$. The sample was then transferred to a new microcentrifuge tube, and a solution containing $100 \mathrm{mM}$ dithiothreitol was added and allowed to rest for $40 \mathrm{~min}$ at $37^{\circ} \mathrm{C}$, followed by the addition of $300 \mathrm{mM}$ of iodoacetamide, being incubated for $30 \mathrm{~min}$ at room temperature in the dark. After incubation, $100 \mu \mathrm{L}$ of $50 \mathrm{mM} \mathrm{AmBic}$ and $10 \mu \mathrm{L}$ of trypsin $2 \%(\mathrm{w} / \mathrm{w})$ were added to the sample and incubated for $14 \mathrm{~h}$ at $37^{\circ} \mathrm{C}$.

After digestion by trypsin, $10 \mu \mathrm{L}$ of blocking solution $(0.1 \%$ trifluoroacetic acid) was added. The samples were desalted and purified using C-18 spin columns (Thermo Fisher Scientific); then they were dried in a rotary evaporator and resuspended in $10 \mu \mathrm{L}$ of 50 $\mathrm{mM}$ AmBic to allow protein quantification by the Bradford method (Bio-Rad Bradford Assays ${ }^{\circledR}$ ). Using this method, it was possible to obtain $80.19,65.23$, and $73.32 \mu \mathrm{g}$ of protein for whole milk, fatfree milk, and water, respectively.

Finally, the samples were dried in a rotary evaporator, resuspended in $3 \%$ acetonitrile with $0.1 \%$ formic acid, and centrifuged at $14,000 \mathrm{~g}$ for $10 \mathrm{~min}$ at $25^{\circ} \mathrm{C}$, and the supernatant was analysed by mass spectrometry (MS).
Shotgun Proteomic Analysis

Peptide identification was performed on a nanoACQUITY UPLC-Xevo QTof MS system (Waters, Manchester, UK). The nanoACQUITY UPLC was equipped with a nanoACQUITY HSS T3 analytical reverse-phase column $(75 \mu \mathrm{m} \times 150 \mathrm{~mm}, 1.8 \mu \mathrm{m}$ particle size; Waters). The column was equilibrated with mobile phase A $(0.1 \%$ formic acid in water). Then, the peptides were separated with a linear gradient of $7-85 \%$ mobile phase B $(0.1 \%$ formic acid in acetonitrile) for $70 \mathrm{~min}$ at a flow rate of $0.35 \mu \mathrm{L} / \mathrm{min}$. The column temperature was maintained at $55^{\circ} \mathrm{C}$. The Xevo G2 Q-TOF mass spectrometer was operated in positive nanoelectrospray ion mode, and data were collected using the $\mathrm{MS}^{\mathrm{E}}$ method in elevated energy (19-45 V), which allows data acquisition of both precursor and fragment ions in a single injection. The source conditions used included: capillary voltage, $2.5 \mathrm{kV}$; sample cone, $30 \mathrm{~V}$; extraction cone, $5.0 \mathrm{~V}$; and source temperature, $80^{\circ} \mathrm{C}$. Data acquisition occurred over $70 \mathrm{~min}$, and the scan range was 50-2,000 Da. The LockSpray, used to ensure accuracy and reproducibility, was run with a [Glu1] fibrinopeptide solution $(1 \mathrm{pmol} / \mu \mathrm{L})$ at a flow rate of $1 \mu \mathrm{L} / \mathrm{min}$, as a reference ion in positive mode at $\mathrm{m} / \mathrm{z} 785.8427$. PLGS (ProteinLynx Global Server) version 3.0 was used to process and search the continuum LC-MS ${ }^{\mathrm{E}}$ data. Proteins were identified with the ion accounting algorithm embedded in the software and a search of the Homo sapiens database (reviewed only; UniProtKB/ Swiss-Prot) downloaded in June 2015 from UniProtKB (http:// www.uniprot.org/). The identified proteins were classified and assigned by biological function [Rison et al., 2000; Zimmerman et al., 2013], origin, and molecular interaction (http://www.uniprot. $\operatorname{org} /$ ).

For a label-free quantitative proteome, $3 \mathrm{MS}$ raw files from each pooled group were analysed using the PLGS software (version 2.2.5; Waters). All proteins identified with scores with a confidence $>95 \%$ were included in the quantitative analysis. Identical peptides from each triplicate by sample were grouped based on mass accu$\operatorname{racy}(<10 \mathrm{ppm})$ and time of retention (tolerance $<0.25 \mathrm{~min}$ ), using the clustering software embedded in the PLGS software. Significant differences in expression between the groups are expressed as $p<0.05$ for downregulated proteins and $1-p>0.95$ for upregulated proteins. The following relevant comparisons were made: whole milk versus fat-free milk, whole milk versus water, and fatfree milk versus water.

\section{Results}

A total of 260 proteins were successfully identified in the AEP samples collected after rinsing with whole milk, fatfree milk, or water. These proteins were classified according to their biological function, origin, and molecular interaction (see online suppl. Table S1; for all online suppl. material, see www.karger.com/doi/10.1159/000485390). It is important to highlight that all these proteins originate from humans, since the Homo sapiens database was used. Thus, neither milk proteins nor bacterial ones were identified in the present study. Of these, 49 were common to all 3 groups (see online suppl. Table S1; Fig. 1). Among the 


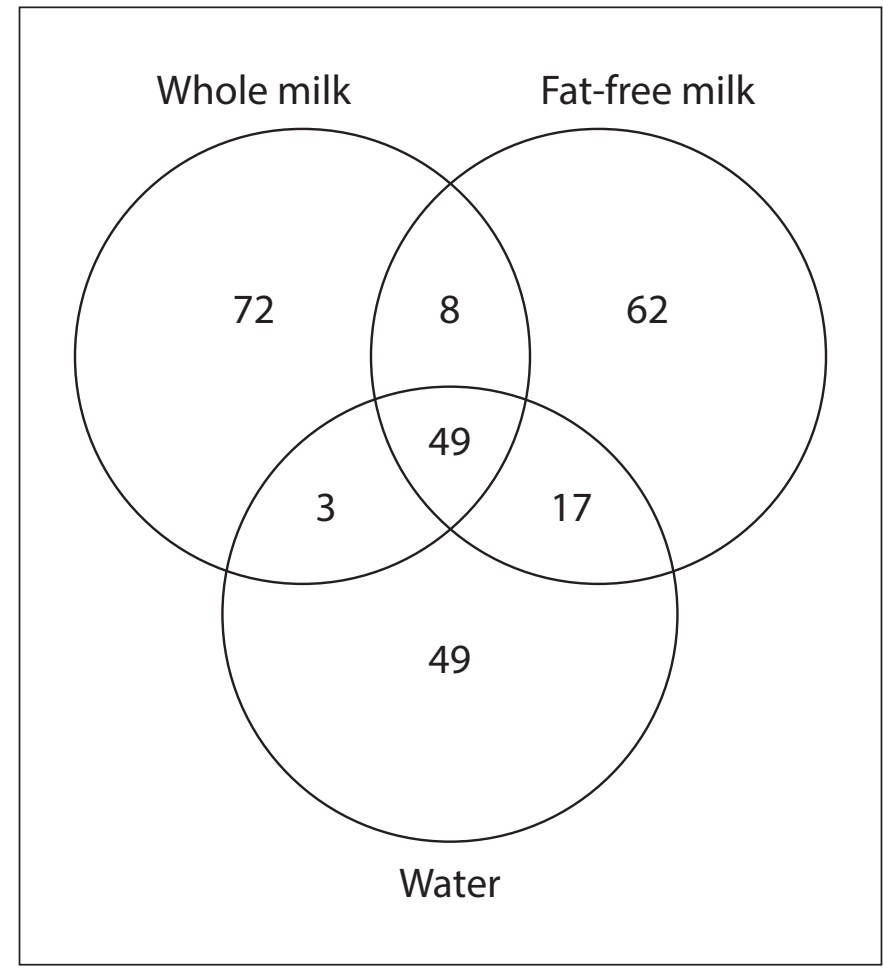

Fig. 1. Venn diagram with the numbers of exclusive proteins in each group and the proteins common to 2 or 3 groups.

proteins found in all the groups were some typical components of the AEP, such as cystatin-B, cystatin-SN, isoforms of $\alpha$-amylase, IgA and $\operatorname{IgG}$, lysozyme $\mathrm{C}$, protein S100 A78, submaxillary gland androgen-regulated protein $3 \mathrm{~B}$, histatin-1, proline-rich protein 27 , statherin, and lactotransferrin. In addition, some proteins with antimicrobial properties, not commonly described as part of the AEP, were also common to all 3 groups, such as myeloblastin, myeloperoxidase, and isoforms of neutrophil defensins.

Eight proteins were common to the AEP after rinsing with whole milk and with fat-free milk. They are histone $\mathrm{H} 4$, heat shock protein beta 1 , keratin type I cytoskeletal 13 , peroxisomal 2,4-dienoyl-CoA reductase, and 4 isoforms of Ig heavy chain V-III. Three proteins were common to the AEP after rinsing with whole milk and with water (azurocidin, cystatin-S, and uncharacterized protein KIAA1109), while another 17 were common after rinsing with fat-free milk and with water. These were 4 isoforms of enolase, 2 isoforms of apolipoprotein $\mathrm{A}$, and proteins associated with iron-binding, i.e., 4 subunits of haemoglobin and LVV-hemorphin 7, 2 isoforms of IgM, and proteins associated with defence, i.e., neutrophil gelatinase-associ-

Proteomics of the Acquired Enamel

Pellicle after Rinsing with Milk
Table 1. Classification and relative quantification of proteins identified in the acquired enamel pellicle collected after rinsing with whole milk (WM) and water (W)

\begin{tabular}{llll}
\hline $\begin{array}{l}\text { Accession } \\
\text { No. }\end{array}$ & Protein name & $\begin{array}{l}\text { WM/W } \\
\text { ratio }\end{array}$ & $p$ \\
\hline Q562R1 & Beta-actin-like protein 2 & 2.61 & 1.00 \\
P04259 & Keratin, type II cytoskeletal 6B & 1.55 & 0.96 \\
P05109 & Protein S100 A8 & 1.46 & 1.00 \\
P05164 & Myeloperoxidase & 1.36 & 1.00 \\
P02808 & Statherin & 1.26 & 1.00 \\
P63261 & Actin, cytoplasmic2 & 0.90 & 0.02 \\
P01876 & Ig alpha-1 chain C region & 0.74 & 0.00 \\
P01877 & Ig alpha-2 chain C region & 0.72 & 0.00 \\
P24158 & Myeloblastin & 0.69 & 0.02 \\
Q9BYX7 & Putative beta-actin-like protein 3 & 0.66 & 0.00 \\
P02814 & Submaxillary gland androgen- & 0.54 & 0.00 \\
& regulated protein 3B & & \\
P15515 & Histatin-1 & 0.47 & 0.00 \\
Q6MZM9 & Proline-rich protein 27 & 0.40 & 0.00 \\
P61626 & Lysozyme C & 0.35 & 0.00 \\
\hline
\end{tabular}

ated lipocalin, peptidoglycan recognition protein, prolactin-inducible protein, and zymogen granule protein 16 homolog B (which binds carbohydrates) (Fig. 1).

After rinsing with whole milk, fat-free milk, and water, 72,62 , and 49 exclusive proteins were identified, respectively (see online suppl. Table S1; Fig. 1). Among the proteins found exclusively in the group rinsing with whole milk were eosinophil peroxidase, large proline-rich protein BAG6, and tuftelin. Among the proteins identified exclusively in the group rinsing with fat-free milk that should be highlighted were basic salivary proline-rich protein and matrix metalloproteinase-28. As for the group rinsing with water, the exclusive proteins with greater relevance were Ig kappa chain $\mathrm{C}$ region and Ig kappa chain V-III region WOL.

Regarding the proteins with differing expression between the groups, in the comparison whole milk versus water (Table 1), 5 proteins were increased and 9 decreased in the group rinsing with whole milk. Among the increased proteins were protein S100 A8, myeloperoxidase, and statherin. Proteins with antimicrobial functions in the AEP, such as histatin-1, lysozyme $\mathrm{C}$, and different isoforms of $\operatorname{IgA}$, were reduced when the pellicle was treated with whole milk. Two PRPs - namely, submaxillary gland androgen-regulated protein $3 \mathrm{~B}$ (proline-rich protein 3 ) and proline-rich protein 27 - were also reduced when the pellicle was treated with whole milk in comparison with water. 
Table 2. Classification and relative quantification of proteins identified in the acquired enamel pellicle collected after rinsing with fat-free milk (FM) and water (W)

\begin{tabular}{|c|c|c|c|}
\hline $\begin{array}{l}\text { Accession } \\
\text { No. }\end{array}$ & Protein name & $\begin{array}{l}\mathrm{FM} / \mathrm{W} \\
\text { ratio }\end{array}$ & $p$ \\
\hline P59665 & Neutrophil defensin 1 & 4.22 & 1.00 \\
\hline Q562R1 & Beta-actin-like protein 2 & 3.49 & 1.00 \\
\hline P69905 & Haemoglobin subunit alpha & 2.72 & 0.99 \\
\hline P59666 & Neutrophil defensin 3 & 2.59 & 1.00 \\
\hline P02768 & Serum albumin & 2.23 & 1.00 \\
\hline P69891 & Haemoglobin subunit gamma-1 & 2.12 & 1.00 \\
\hline P68871 & Haemoglobin subunit beta & 2.08 & 1.00 \\
\hline P02042 & Haemoglobin subunit delta & 2.08 & 1.00 \\
\hline P02100 & Haemoglobin subunit epsilon & 2.05 & 1.00 \\
\hline F8W6P5 & LVV-hemorphin-7 (fragment) & 2.05 & 1.00 \\
\hline P69892 & Haemoglobin subunit gamma-2 & 2.03 & 0.99 \\
\hline C9JKR2 & Albumin, isoform CRA_k & 1.55 & 1.00 \\
\hline P05109 & Protein S100 A8 & 1.55 & 1.00 \\
\hline Q8IUK7 & ALB protein & 1.54 & 1.00 \\
\hline P01859 & Ig gamma- 2 chain $\mathrm{C}$ region & 1.51 & 1.00 \\
\hline P01861 & Ig gamma- 4 chain $\mathrm{C}$ region & 1.49 & 0.98 \\
\hline P01860 & Ig gamma-3 chain $\mathrm{C}$ region & 1.46 & 0.97 \\
\hline P02788 & Lactotransferrin & 1.39 & 1.00 \\
\hline P02808 & Statherin & 1.14 & 0.99 \\
\hline P60709 & Actin, cytoplasmic 1 & 0.87 & 0.00 \\
\hline P63261 & Actin, cytoplasmic 2 & 0.87 & 0.00 \\
\hline P01876 & Ig alpha-1 chain $\mathrm{C}$ region & 0.83 & 0.01 \\
\hline P01877 & Ig alpha- 2 chain $\mathrm{C}$ region & 0.82 & 0.00 \\
\hline P19961 & Alpha-amylase 2B & 0.81 & 0.03 \\
\hline P04745 & Alpha-amylase 1 & 0.80 & 0.02 \\
\hline Q5T085 & Alpha-amylase (fragment) & 0.73 & 0.01 \\
\hline P02814 & $\begin{array}{l}\text { Submaxillary gland androgen- } \\
\text { regulated protein } 3 \mathrm{~B}\end{array}$ & 0.66 & 0.00 \\
\hline Q6MZM9 & Proline-rich protein 27 & 0.66 & 0.00 \\
\hline P25311 & Zinc-alpha-2-glycoprotein & 0.63 & 0.04 \\
\hline
\end{tabular}

When the group rinsing with fat-free milk was compared to that rinsing with water (Table 2), 19 proteins were increased, while 10 were decreased. Among the increased proteins were statherin, protein $\mathrm{S} 100 \mathrm{~A} 8$, isoforms of IgG, neutrophil defensins, subunits of haemoglobin, LVV-hemorphin 7, and lactotransferrin. Other antimicrobial proteins, however, were reduced when the AEP was treated with fat-free milk, such as isoforms of IgA. Different isoforms of amylase, proteins with digestive function on carbohydrates, were also reduced upon treatment with fat-free milk. In addition, the same PRPs that were found to be reduced in the group rinsing with whole milk (proline-rich protein 3 and proline-rich protein 27) were also reduced upon treatment with fat-free milk when compared with water, albeit to a lower extent.
Table 3. Classification and relative quantification of the proteins identified in the acquired enamel pellicle collected after rinsing with whole milk (WM) and fat-free milk (FM)

\begin{tabular}{|c|c|c|c|}
\hline $\begin{array}{l}\text { Accession } \\
\text { No. }\end{array}$ & Protein name & $\begin{array}{l}\mathrm{WM} / \mathrm{FM} \\
\text { ratio }\end{array}$ & $p$ \\
\hline J3KT65 & $\begin{array}{l}\text { Actin, cytoplasmic } 2, \mathrm{~N} \text {-terminally } \\
\text { processed }\end{array}$ & 1.35 & 0.97 \\
\hline P0CG38 & $\begin{array}{l}\text { POTE ankyrin domain family } \\
\text { member I }\end{array}$ & 1.32 & 1.00 \\
\hline P05164 & Myeloperoxidase & 1.17 & 0.97 \\
\hline P02808 & Statherin & 1.11 & 0.98 \\
\hline P02814 & $\begin{array}{l}\text { Submaxillary gland androgen- } \\
\text { regulated protein } 3 \mathrm{~B}\end{array}$ & 0.81 & 0.00 \\
\hline P02788 & Lactotransferrin & 0.79 & 0.00 \\
\hline Q562R1 & Beta-actin-like protein 2 & 0.75 & 0.01 \\
\hline Q9BYX7 & Putative beta-actin-like protein 3 & 0.74 & 0.00 \\
\hline P01860 & Ig gamma-3 chain $\mathrm{C}$ region & 0.64 & 0.04 \\
\hline C9JKR2 & Albumin, isoform CRA_k & 0.64 & 0.00 \\
\hline Q8IUK7 & ALB protein & 0.64 & 0.00 \\
\hline P01859 & Ig gamma-2 chain $\mathrm{C}$ region & 0.63 & 0.04 \\
\hline Q6MZM9 & Proline-rich protein 27 & 0.61 & 0.01 \\
\hline P02768 & Serum albumin & 0.56 & 0.00 \\
\hline P69892 & Haemoglobin subunit gamma-2 & 0.53 & 0.03 \\
\hline P15515 & Histatin-1 & 0.51 & 0.00 \\
\hline P59666 & Neutrophil defensin 3 & 0.46 & 0.00 \\
\hline Q9NUI1 & $\begin{array}{l}\text { Peroxisomal 2,4-dienoyl-CoA } \\
\text { reductase }\end{array}$ & 0.46 & 0.01 \\
\hline P03973 & Antileukoproteinase & 0.45 & 0.00 \\
\hline P59665 & Neutrophil defensin 1 & 0.29 & 0.00 \\
\hline P61626 & Lysozyme C & 0.29 & 0.00 \\
\hline
\end{tabular}

As for the comparison whole milk versus fat-free milk (Table 3), 4 proteins were significantly increased in whole milk, such as actin cytoplasmic $2 \mathrm{~N}$-terminally processed, POTE ankyrin domain family member I, statherin, and myeloperoxidase. Other proteins were significantly reduced in the group rinsing with whole milk when compared with fat-free milk. Among them were Ig gamma- 2 chain $C$ region, Ig gamma-3 chain $C$ region, histatin-1, neutrophil defensin 1 , neutrophil defensin 3, lysozyme C, peroxisomal 2,4-dienoyl-CoA reductase, and PRPs.

\section{Discussion}

The study's null hypothesis was rejected, since pronounced changes occurred in the proteomic profile of the AEP after rinsing with whole milk, fat-free milk, or deionized water. 
The total number of proteins identified was greater than previously reported in other in vivo studies [Siqueira et al., 2007; Zimmerman et al., 2013; Delecrode et al., 2015a], which might be due to the protocol employed to extract the proteins as well as to the rinses with milk that might have allowed different proteins to adsorb on the AEP. In order to have enough samples for analysis, we pooled the AEP samples collected from the 9 volunteers in each group. This procedure has been used in all the studies involving quantitative proteomic analysis of the AEP, since the tiny amount of protein that can be obtained from a single volunteer precludes individual analysis of the AEP [Lee et al., 2013; Delecrode et al., 2015a; de Souza-e-Silva et al., 2017; Ventura et al., 2017]. A recent study conducted in situ where the acquired pellicle was formed on dental ceramic specimens that allowed obtaining enough material for individual analysis revealed significant differences in protein amount between subjects, but high interday consistency, indicating unique, individual pellicle profiles [Delius et al., 2017]. Considering that our study had a crossover design, we can assume that the differences observed between the pooled samples were due to the treatments, since the same profile could be expected for each individual on all the days of pellicle collection. Moreover, for each group, the pooled samples were analysed in triplicate. Furthermore, since only the proteins identified in all 3 runs with scores with confidence $>95 \%$ were included in the comparative analysis, the quantification by the MS procedure can be regarded as accurate.

In the present study we employed an in vivo model, which has the main advantage of allowing the natural formation of the acquired pellicle over enamel. However, the main limitation of the model is the tiny amount of protein that can be recovered, as stated above, thus not allowing individual analyses of the AEP. Moreover, collection of the AEP formed in vivo is usually done rubbing filter papers embedded in solutions for disrupting protein interactions. However, the possibility cannot be excluded that this procedure does not remove the whole pellicle, especially the basal one. In the present study, following previous protocols [Siqueira et al., 2007], we employed a filter paper embedded in a highly concentrated citric acid (3\%), which is expected to remove, if not all, nearly all the proteins within the AEP. In fact, a pilot study (data not shown) revealed that after a first collection of AEP proteins using this procedure, a second collection does not lead to additional removal (as evaluated by protein analysis using the Bradford method), corroborating our hypothesis. However, it would be interesting to evaluate the

Proteomics of the Acquired Enamel Pellicle after Rinsing with Milk degree of removal of AEP proteins by this collection method using other techniques, such as transmission electron microscopy. In situ protocols have also been employed in studies involving proteomic analysis of the acquired pellicle. The in situ models are particularly useful for some conditions that cannot be easily reproduced in vivo, such as the acquired pellicle formed over dentine specimens [Delecrode et al., 2015b]. Another advantage of in situ models is that they allow the use of sonication for pellicle collection, which makes total recovery of the pellicle proteins easier [Delius et al., 2017].

Four isoforms of Ig heavy chain V-III were found both in the whole milk and the fat-free milk group. Since milk is rich in immunoglobulins, we cannot rule out the possibility that these heavy chains of Ig come from milk, even though the Homo sapiens database was employed for identifying the peptides derived from the action of trypsin on the acquired pellicle proteins. In this case, it is possible that the peptides that originated from the action of trypsin have the same amino acid sequence in humans and bovines, since these immunoglobulins were identified only in the groups rinsing with milk, but not in the group rinsing with water.

Most of the proteins identified exclusively in the group rinsing with whole milk were intracellular proteins associated with different functions in the organism, such as metabolism, cell signalling, cell adhesion, cell division, transport, and protein synthesis and degradation, and they are not typically found in the AEP. Thus, their role in the AEP cannot be anticipated. Eosinophil peroxidase, one of the proteins found exclusively in the group rinsing with whole milk, despite not being described as a component of the AEP before might play a role in the defence against microorganisms. Another protein exclusive to the group rinsing with whole milk was large proline-rich protein BAG6, which plays a role in antigen presentation in immune response. Tuftelin, involved in the mineralization and structural organization of enamel, was also identified exclusively in the group rinsing with whole milk. Although the exclusive proteins found in the whole milk group are not typical components of the AEP, their presence might provide mechanical protection against acid attacks on enamel. The clinical relevance of these findings should be tested in future studies.

The proteins identified exclusively in the group rinsing with fat-free milk are also involved in metabolism, biological processes, transport, information pathways, and protein synthesis and degradation. Their role in the AEP, however, is unknown so far. Another protein uniquely identified in this group is basic salivary proline- 
rich protein, which is a major component of parotid and submandibular saliva and strongly binds calcium, indicating that it may be important in maintaining the concentration of ionic calcium in saliva [Bennick, 1982]. Interestingly, matrix metalloproteinase- 28 was also found in this group. This protein can degrade casein and also plays a role in tissue homoeostasis and repair [UniProt Consortium, 2017]. The exclusive proteins identified in the group rinsing with water are mostly related to metabolism, biological processes, and information pathways. Proteins with a role in immune defence and antibacterial function were also found, like Ig kappa chain C region, with a function of antigen binding, and Ig kappa chain V-III region WOL, both playing an important role in primary defence mechanisms. They have been shown to be involved in early recognition of external invaders such as bacteria and viruses [UniProt Consortium, 2017].

Considering the difference in expression between the groups, in the comparison whole milk versus water (Table 1), among the proteins increased in the first group, statherin is regarded as a precursor protein in the AEP, since it selectively adsorbs on apatite [Hay, 1973]. It is important to maintain a state of supersaturation regarding calcium and phosphate in the oral fluids [Helmerhorst et al., 2010]. Besides, it is a determinant of initial microbial colonization of the tooth surface, since it facilitates binding of Actinomyces viscosus [Clark et al., 1984, 1986; Gibbons and Hay, 1988; Gibbons et al., 1988] and F. nucleatum [Xie et al., 1991]. The increase in the concentration of statherin in the AEP treated with whole milk in comparison with fat-free milk, albeit significant, was discrete (1.26-fold). The implication of these findings must be investigated in the future. Protein S100, which was more highly expressed in the whole milk group, is a calcium- and zinc-binding protein that has been described in the enamel pellicle [Masson et al., 2013], but its role in this integument remains to be elucidated. While myeloperoxidase was increased in the AEP treated with whole milk, other classic proteins with antimicrobial functions in the AEP, such as histatin-1, lysozyme $\mathrm{C}$, and different isoforms of IgA, were reduced when the pellicle was treated with whole milk, as well as 2 PRPs. PRPs, together with mucins, statherin, and histatins, are pellicle precursor proteins, since they have a high affinity to hydroxyapatite [Hay and Moreno, 1979; Jensen et al., 1992], and possibly control erosion and caries by modulating phosphate and calcium concentrations within the oral cavity. They are able to inhibit the precipitation of calcium and phosphate at a neutral $\mathrm{pH}$ and to release these ions after acidic attacks [Hay and Moreno, 1979]. In ad- dition, transglutaminase cross-links with PRPs, which reduces conformational changes, thus conferring resistance to the AEP [Hannig et al., 2009]. Recently, PRPs in the AEP were shown to be resistant to removal by citric and lactic acids in the AEP [Delecrode et al., 2015a], which reinforces their protective role against acidic dissolution. Accordingly, PRPs are increased in saliva and the pellicle of caries-free subjects [Vitorino et al., 2005, 2006]. These results suggest that treatment of AEPs with whole milk might decrease the level of these protective proteins. The effect of this change in respect to the prevention of caries/ erosion should be further investigated.

For the comparison between the groups rinsing with fat-free milk and water (Table 2), statherin and protein S100 A8 were increased with both types of milk in comparison to water. This might be due to the ability of these proteins to bind calcium [Jensen et al., 1992; Masson et al., 2013]. Various proteins associated with host defence were also increased in the group rinsing with fat-free milk. Some of them are classically described as antimicrobial components of the AEP, such as isoforms of IgG [Siqueira et al., 2007], while others, such as neutrophil defensins, are potentially new antimicrobial players in the AEP. These proteins have antibacterial, fungicidal, and antiviral activities, possessing antimicrobial activities against both gram-positive and -negative bacteria. They kill microbes by permeabilizing their plasma membranes [UniProt Consortium, 2017]. Iron-binding proteins, such as different subunits of haemoglobin, LVV-hemorphin-7, and lactotransferrin, were also increased when the AEP was treated with fat-free milk. The latter also possess antimicrobial properties by sequestering free iron, thus inhibiting microbial growth [UniProt Consortium, 2017]. Isoforms of IgA were reduced upon treatment with fat-free milk. This might be due to competition with casein for interaction with proteins present on the enamel surface. A previous study that evaluated in vitro the adsorption of milk proteins on tooth enamel showed that when the $\mathrm{pH}$ is neutral, caseins are the main proteins present on the enamel surface after incubation with fatfree milk [Devold et al., 2005].

Comparing whole milk and fat-free milk (Table 3), of the proteins which were significantly increased after rinsing with whole milk, myeloperoxidase is included among the typical proteins found in the AEP, but it is implicated in the host defence system of polymorphonuclear leukocytes, being responsible for microbicidal activity against a wide range of microorganisms [UniProt Consortium, 2017]. Classic proteins associated with defence against microorganisms in the AEP were significantly reduced in 
the group rinsing with whole milk when compared with fat-free milk, such as Ig gamma- 2 chain $\mathrm{C}$ region, Ig gamma-3 chain $C$ region, histatin-1, neutrophil defensin 1 , neutrophil defensin 3, and lysozyme C. Peroxisomal 2,4dienoyl-CoA reductase, an auxiliary enzyme of $\beta$-oxidation that participates in the degradation of unsaturated fatty enoyl-CoA esters, was also reduced upon treatment with whole milk in comparison with fat-free milk. PRPs, such as submaxillary gland androgen-regulated protein 3B (proline-rich protein 3) and proline-rich protein 27, were also reduced when the pellicle was treated with whole milk in comparison with fat-free milk. In fact, treatment with milk, regardless of its fat content, reduced these PRPs in comparison with water, even though the reduction was less pronounced with fat-free milk.

The present findings suggest that treatment of the AEP with fat-free milk might be more beneficial in terms of antimicrobial properties and biofilm formation as compared to whole milk, a conclusion which should be confirmed in further studies. However, more information about the fat content and thickness of the AEP treated with different types of milk is needed, since these variables can also play an important role in the protective ef- fect. Further studies testing the protective effect of the AEP treated with whole and fat-free milk against demineralization (caries/erosion) should be conducted, to confirm the clinical relevance of these findings.

\section{Acknowledgements}

This study was supported by The Borrow Foundation. The authors thank FAPESP for the grant of a PhD scholarship to the first author (process No. 2014/22430-0). The funders had no role in the study design, data collection, and analysis, the decision to publish, or the preparation of the manuscript.

\section{Disclosure Statement}

The authors declare no conflict of interest.

\section{Author Contributions}

Conceived and designed the experiments: M.A.R.B., A.C.M., J.P.P. Performed the experiments: L.P.S.C., T.M.S.V., C.M.S.S., A.L.L. Analyzed the data: T.M.S.V., M.A.R.B. Drafted and revised the manuscript: All the authors.

\section{References}

Bennick A: Salivary proline-rich proteins. Mol Cell Biochem 1982;45:83-99.

Bowen WH, Pearson SK, VanWuyckhuyse BC, Tabak LA: Influence of milk, lactose-reduced milk, and lactose on caries in desalivated rats. Caries Res 1991;25:283-286.

Buzalaf MA, Hannas AR, Kato MT: Saliva and dental erosion. J Appl Oral Sci 2012;20:493502.

Cheaib Z, Rakmathulina E, Lussi A, Eick S: Impact of acquired pellicle modification on adhesion of early colonizers. Caries Res 2015;49: 626-632.

Clark WB, Wheeler TT, Cisar JO: Specific inhibition of adsorption of Actinomyces viscosus $\mathrm{T} 14 \mathrm{~V}$ to saliva-treated hydroxyapatite by antibody against type 1 fimbriae. Infect Immun 1984;43:497-501.

Clark WB, Wheeler TT, Lane MD, Cisar JO: Actinomyces adsorption mediated by type- 1 fimbriae. J Dent Res 1986;65:1166-1168.

Delecrode TR, Siqueira WL, Zaidan FC, Bellini MR, Moffa EB, Mussi MC, Xiao Y, Buzalaf MA: Identification of acid-resistant proteins in acquired enamel pellicle. J Dent 2015a;43: $1470-1475$.

Delecrode TR, Siqueira WL, Zaidan FC, Bellini MR, Leite AL, Xiao Y, Rios D, Magalhães AC, Buzalaf MA: Exposure to acids changes the proteomic of acquired dentine pellicle. J Dent 2015b;43:583-588.
Delius J, Tratmann S, Médard G, Kuster B, Hannig M, Hofmann T: Label-free quantitative proteome analysis of the surface-bound salivary pellicle. Colloids Surf B Biointerfaces 2017;152:68-76.

de Souza-e-Silva CM, da Silva Ventura TM, de Paula Silva Cassiano L, de Lima Leite A, Buzalaf MA: Effect of gels containing chlorhexidine or epigallocatechin-3-gallate on the protein composition of the acquired enamel pellicle. Arch Oral Biol 2017;82:92-98.

Devold TG, Rykke M, Isabey D, Sørensen ES, Christensen B, Langsrud T, Svenning C, BorchIohnsen B, Karlsen J, Vegarud GE: In vitro studies of adsorption of milk proteins onto tooth enamel. Int Dairy J 2006;16:1013-1017.

Gibbons RJ, Hay DI: Human salivary acidic proline-rich proteins and statherin promote the attachment of Actinomyces viscosus LY7 to apatitic surfaces. Infect Immun 1988;56:439445.

Gibbons RJ, Hay DI, Cisar JO, Clark WB: Adsorbed salivary proline-rich protein 1 and statherin: receptors for type 1 fimbriae of $A c$ tinomyces viscosus T14V-J1 on apatitic surfaces. Infect Immun 1988;56:2990-2993.

Gibbons RJ, Hay DI, Schlesinger DH: Delineation of a segment of adsorbed salivary acidic proline-rich proteins which promotes adhesion of Streptococcus gordonii to apatitic surfaces. Infect Immun 1991;59:2948-2954.
Hannig C, Spitzmüller B, Hannig M: Transaminases in the acquired pellicle. Arch Oral Biol 2009;54:445-448.

Hannig M, Fiebiger M, Güntzer M, Döbert A, Zimehl R, Nekrashevych Y: Protective effect of the in situ formed short-term salivary pellicle. Arch Oral Biol 2004;49:903-910.

Hannig C, Wagenschwanz C, Pötschke S, Kümmerer K, Kensche A, Hoth-Hannig W, Hannig M: Effect of safflower oil on the protective properties of the in situ formed salivary pellicle. Caries Res 2012;46:496-506.

Hara AT, Ando M, González-Cabezas C, Cury JA, Serra MC, Zero DT: Protective effect of the dental pellicle against erosive challenges in situ. J Dent Res 2006;85:612-616.

Hay DI: The isolation from human parotid saliva of a tyrosine-rich acidic peptide which exhibits high affinity for hydroxyapatite surfaces. Arch Oral Biol 1973;18:1531-1541.

Hay DI, Moreno EC: Differential adsorption and chemical affinities of proteins for apatitic surfaces. J Dent Res 1979;58:930-942.

Helmerhorst EJ, Traboulsi G, Salih E, Oppenheim FG: Mass spectrometric identification of key proteolytic cleavage sites in statherin affecting mineral homeostasis and bacterial binding domains. J Proteome Res 2010;9:5413-5421.
Proteomics of the Acquired Enamel Pellicle after Rinsing with Milk 
Jensen JL, Lamkin MS, Oppenheim FG: Adsorption of human salivary proteins to hydroxyapatite: a comparison between whole saliva and glandular salivary secretions. J Dent Res 1992;71:1569-1576.

Kensche A, Reich M, Kümmerer K, Hannig M, Hannig C: Lipids in preventive dentistry. Clin Oral Investig 2013;17:669-685.

Kolenbrander PE, London J: Adhere today, here tomorrow: oral bacterial adherence. J Bacteriol 1993;175:3247-3252.

Lee YH, Zimmerman JN, Custodio W, Xiao Y, Basiri T, Hatibovic-Kofman S, Siqueira WL: Proteomic evaluation of acquired enamel pellicle during in vivo formation. PLoS One 2013;8:e67919.

Lendenmann U, Grogan J, Oppenheim FG: Saliva and dental pellicle - a review. Adv Dent Res 2000;14:22-28.

Li J, Helmerhorst EJ, Leone CW, Troxler RF, Yaskell T, Haffajee AD, Socransky SS, Oppenheim FG: Identification of early microbial colonizers in human dental biofilm. J Appl Microbiol 2004;97:1311-1318.

Magalhães AC, Levy FM, Souza BM, Cardoso CA, Cassiano LP, Pessan JP, Buzalaf MA: Inhibition of tooth erosion by milk containing different fluoride concentrations: an in vitro study. J Dent 2014;42:498-502.

Masson N, Domingues RR, Cury JA, Paes Leme AF: Acidulated phosphate fluoride application changes the protein composition of human acquired enamel pellicle. Caries Res 2013;47:251-258.
Reynolds EC, Black CL, Cai F, Cross KJ, Eakins D, Huq NL, et al: Advances in enamel remineralization: casein phosphopeptide-amorphous calcium phosphate. J Clin Dent 1999;10:8688.

Rison SC, Hodgman TC, Thornton JM: Comparison of functional annotation schemes for genomes. Funct Integr Genomics 2000;1:56-69.

Scannapieco FA, Bergey EJ, Reddy MS, Levine MJ: Characterization of salivary alpha-amylase binding to Streptococcus sanguis. Infect Immun 1989;57:2853-2863.

Siqueira WL, Custodio W, McDonald EE: New insights into the composition and functions of the acquired enamel pellicle. J Dent Res 2012;91:1110-1118.

Siqueira WL, Zhang W, Helmerhorst EJ, Gygi SP, Oppenheim FG: Identification of protein components in in vivo human acquired enamel pellicle using LC-ESI-MS/MS. J Proteome Res 2007;6:2152-2160.

Slomiany BL, Murty VL, Zdebska E, Slomiany A, Gwozdzinski K, Mandel ID: Tooth surfacepellicle lipids and their role in the protection of dental enamel against lactic-acid diffusion in man. Arch Oral Biol 1986;31:187-191.

UniProt Consortium: UniProt: the universal protein knowledgebase. Nucleic Acids Res 2017; 45:D158-D169.

Vacca-Smith AM, Bowen WH: Binding properties of streptococcal glucosyltransferases for hydroxyapatite, saliva-coated hydroxyapatite, and bacterial surfaces. Arch Oral Biol 1998;43:103-110

Vacca-Smith AM, Bowen WH: The effects of milk and kappa-casein on salivary pellicle formed on hydroxyapatite discs in situ. Caries Res 2000;34:88-93.
Ventura TMDS, Cassiano LPS, Souza e Silva CM, Taira EA, Leite AL, Rios D, Buzalaf MAR: The proteomic profile of the acquired enamel pellicle according to its location in the dental arches. Arch Oral Biol 2017;79:20-29.

Vitorino R, de Morais Guedes S, Ferreira R, Lobo MJ, Duarte J, Ferrer-Correia AJ, Tomer KB, Domingues PM, Amado FM: Two-dimensional electrophoresis study of in vitro pellicle formation and dental caries susceptibility. Eur J Oral Sci 2006;114:147-153.

Vitorino R, Lobo MJ, Duarte JR, Ferrer-Correia AJ, Domingues PM, Amado FM: The role of salivary peptides in dental caries. Biomed Chromatogr 2005; 19:214-222.

Vukosavljevic D, Custodio W, Buzalaf MA, Hara AT, Siqueira WL: Acquired pellicle as a modulator for dental erosion. Arch Oral Biol 2014; 59:631-638.

Warner EA, Kanekanian AD, Andrews AT: Bioactivity of milk proteins: 1 . Anticariogenicity of whey proteins. Int J Dairy Technol 2001;54: 151-153.

Xie H, Gibbons RJ, Hay DI: Adhesive properties of strains of Fusobacterium nucleatum of the subspecies nucleatum, vincentii and polymorphum. Oral Microbiol Immunol 1991;6:257263.

Zimmerman JN, Custodio W, Hatibovic-Kofman S, Lee YH, Xiao Y, Siqueira WL: Proteome and peptidome of human acquired enamel pellicle on deciduous teeth. Int J Mol Sci 2013; 14:920-934. 